Paulina ŚWIERK ${ }^{1}$, Elżbieta MACIOSZEK ${ }^{2}$, Aleksander SOBOTA ${ }^{3}$

DOI: https://doi.org/10.53052/9788366249851.07

\title{
THE TICKET TARIFF AND DISTRIBUTION CHANNELS IN THE GóRnoŚląSKA- ZAGŁęBIOWSKA METROPOLIS
}

Summary: Transport tariff is significant factor impacts on the demand for public transport. The attractiveness and legibility of tariff and easy access to the ticket distribution channels is important for passengers. The purpose of this article is presentation of solutions in the field of transport tariff in public transport in force in the Metropolis GZM. In addition, the ticket distribution channels for single and season tickets were characterized.

Keywords: traffic engineering, public transport, transport tariff, ticket distribution channels, road transport.

\section{TARYFA PRZEWOZU I KANAŁY DYSTRYBUCJI BILETÓW OBOWIĄZUJĄCE NA TERENIE GÓRNOŚLĄSKO- ZAGEĘBIOWSKIEJ METROPOLII}

Streszczenie: Taryfa przewozu to istotny czynnik wpływający na popyt na komunikację miejską. Dla pasażerów ważna jest atrakcyjność i czytelność taryfy oraz łatwy dostęp do kanałów dystrybucji biletów. Celem niniejszego artykułu jest prezentacja rozwiązań z zakresu taryfy przewozowej $\mathrm{w}$ publicznym transporcie zbiorowym obowiązujących na terenie Górnośląsko- Zagłębiowskiej Metropolii. Dodatkowo scharakteryzowano kanały dystrybucji biletów jednorazowych i okresowych.

Słowa kluczowe: inżynieria ruchu, publiczny transport zbiorowy, taryfa przewozowa, kanały sprzedaży biletów.

\section{Introduction}

The dynamic development of polish cities and the related changes in lifestyle contribute to the growth of transport needs [1]. The constantly increasing vehicles number contributes to increasing in the noise level, congestion in cities, deterioration

$1 \mathrm{PhD}$ Student, Silesian University of Technology, Faculty of Transport and Aviation Engineering, e-mail: paulina.swierk@polsl.pl

2 PhD, DSc, Eng., Prof. SUT, Silesian University of Technology, Faculty of Transport and Aviation Engineering, e-mail: elzbieta.macioszek@polsl.pl

3 PhD, DSc, Eng., Prof. SUT, Silesian University of Technology, Faculty of Transport and Aviation Engineering, e-mail: aleksander.sobota@polsl.pl 
of the road infrastructure, increasing exhaust emissions, air pollution [2-4]. This situation causes the deterioration of life quality [5]. To minimize the abovementioned consequences, local government units organizing public transport should increase its attractiveness. This action can be achieved by ensuring a good transport offer and an attractive, clear ticket tariff [7].

The Górnośląska- Zagłębiowska Metropolis (GZM) is the first metropolitan union created in Poland, which mobilize 41 Cities of The Silesian Voivodeship [10]. In 2017, the Congregation of Górnośląska- Zagłębiowska Metropolis has decided to adopt the resolution on creating organizational unit of the GZM called Zarzad Transportu Metropolitalnego (ZTM) [9]. This action has resulted in the integration of three public transport organizers: the KZK GOP, the MZK Tychy and the MZKP Tarnowskie Góry. The main task of ZTM is planning, organization and management of public transport. The article presents solutions in the field of ticket tariff in public transport. Additionaly there were charakterised the ticket distribution channels, which can be used while purchasing a ticket. The locations of stationary points of sale were presented using the qGIS software.

\section{Characteristics of the Zarząd Transportu Metropolitalnego}

Zarząd Transportu Metropolitalnego (ZTM) is local government unit, which was established by the Congregation of Górnośląska- Zagłębiowska Metropolis on January 1, 2019. ZTM became the only public transport organizer in the GZM. The ZTM serves 51 cities and communes, connecting the most important centers of The Silesian Voivodeship. This action has resulted in the integration of three public transport organizers: the KZK GOP, the MZK Tychy and the MZKP Tarnowskie Góry [11].

In the area covered by the ZTM activity it functions:

- 10 metropolitan bus lines,

- 4 express airport bus lines,

- 372 normal bus lines,

- 23 night bus lines,

- $\quad 32$ tram lines,

- 7 trolley-bus lines [12].

The above-mentioned communication lines, functioning in the area of The Górnośląska- Zagłębiowska Metropolis, are served by 40 public transport operators [12].

The result of the establishment of The ZTM was the tariff integration, which is the integration process of various public transport organizers. The purpose of this action was to facilitate passengers the use of public transport in the GZM area and to increase the share of public transport in overall travels.

\section{The ticket tariff in Górnośląska- Zagłębiowska Metropolis}

The ticket tariff is usually a publicly available price list of public transport services along with the rules of their use. It is made public. The prices for the shipping service in public transport are element of the transport policy and are subject of regulation [6]. 
Taking into account the criterion of the method of taking into account the travel distance, there are three basic types of tariffs:

- unified,

- $\quad$ section (time and distance),

- $\quad$ zonal [8].

In the area of the ZTM, "Taryfa przewozów osób i bagażu w komunikacji zbiorowej organizowanej przez Zarząd Transportu Metropolitalnego" is valid. It is the attachment to [9] and it determines the applicable ticket prices.

In the Górnośląska- Zagłębiowska Metropolis there are two types of tickets: paper and electronic.

The following types of tickets are distinguished in the Górnośląska- Zagłębiowska Metropolis area:

- a single/ short-term tickets issued in paper and electronic form,

- $\quad$ an electronic toll for a single/ short-term trip according to the distance tariff,

- $\quad$ mid-term tickets issued in paper and electronic form,

- $\quad$ long-term tickets issued in electronic form,

- monthly METROTICKETS issued in electronic form,

- "Group ticket for 5 people" issued in paper and electronic form.

Additionally, passengers can use the ZTM services on the basis of individual tickets issued by Koleje Śląskie sp. z o.o. [9]. The table 1 presents the pricelist of the single/ short-term tickets price list issued in paper and electronic form.

Table 1. The pricelist of single/ short-term tickets [9]

\begin{tabular}{|c|c|c|c|c|c|}
\hline \multirow{2}{*}{$\begin{array}{l}\text { The symbol } \\
\text { of the ticket }\end{array}$} & \multirow{2}{*}{ The type of ticket } & \multicolumn{2}{|c|}{$\begin{array}{c}\text { Normal ticket price } \\
{[\text { PLN] }}\end{array}$} & \multicolumn{2}{|c|}{$\begin{array}{l}\text { Half-price ticket } \\
\text { price [PLN] }\end{array}$} \\
\hline & & $\begin{array}{l}\text { Electronic } \\
\text { form }\end{array}$ & $\begin{array}{l}\text { Paper } \\
\text { form }\end{array}$ & $\begin{array}{l}\text { Electronic } \\
\text { form }\end{array}$ & $\begin{array}{l}\text { Paper } \\
\text { form }\end{array}$ \\
\hline $1 \mathrm{city} / 20 \mathrm{~min}$ & $\begin{array}{l}\text { A single trip within one } \\
\text { city or for } 20 \text { minutes } \\
\text { from validation (with the } \\
\text { possibility of transfer } \\
\text { connections) }\end{array}$ & 3,60 & 4,00 & 1,80 & 2,00 \\
\hline 2 cities $/ 40 \mathrm{~min}$ & $\begin{array}{l}\text { A single trip within two } \\
\text { cities or for } 40 \text { minutes } \\
\text { from validation (with the } \\
\text { possibility of transfer } \\
\text { connections) }\end{array}$ & 4,40 & 5,00 & 2,20 & 2,50 \\
\hline $\begin{array}{c}\text { The network/90 } \\
\text { min }\end{array}$ & $\begin{array}{l}\text { A single trip within three } \\
\text { or more cities or for } 90 \\
\text { minutes from validation } \\
\text { (with the possibility of } \\
\text { transfer connections) }\end{array}$ & 5,40 & 6,00 & 2,70 & 3,00 \\
\hline
\end{tabular}

As we can see in the table 1, tickets bought in electronic form are more economical. The table 2 presents an electronic toll for a single/ short-term trip according to the distance tariff. 
Table 2. An electronic toll for a single/short term trip accorfind to the distance tariff [9]

\begin{tabular}{|c|c|c|}
\hline The distance range & Normal ticket price [PLN] & Half-price ticket price [PLN] \\
\hline to $1,0 \mathrm{~km}$ & 1,80 & 0,90 \\
\hline from $1,0 \mathrm{~km}$ to $2,0 \mathrm{~km}$ & 2,40 & 1,20 \\
\hline from $2,0 \mathrm{~km}$ to $5,0 \mathrm{~km}$ & 2,80 & 1,40 \\
\hline from $5,0 \mathrm{~km}$ to $9,0 \mathrm{~km}$ & 3,40 & 1,70 \\
\hline from $9,0 \mathrm{~km}$ to $14,0 \mathrm{~km}$ & 3,90 & 1,95 \\
\hline from $14,0 \mathrm{~km}$ to $20,0 \mathrm{~km}$ & 4,30 & 2,15 \\
\hline over $20,0 \mathrm{~km}$ & 5,00 & 2,50 \\
\hline
\end{tabular}

The table 3 presents the pricelist of the mid-term tickets issued in paper and electronic form. The price in both form is the same.

Table 3. The pricelist of mid-term tickets issued in paper and electronic form [9]

\begin{tabular}{|c|l|c|c|}
\hline $\begin{array}{c}\text { The } \\
\text { symbol } \\
\text { of the } \\
\text { ticket }\end{array}$ & The type of ticket & $\begin{array}{c}\text { Normal } \\
\text { ticket price } \\
\text { [PLN] }\end{array}$ & $\begin{array}{c}\text { Half-price } \\
\text { ticket price } \\
\text { [PLN] }\end{array}$ \\
\hline Day pass & $\begin{array}{l}\text { The ticket valid in the ZTM area, from the activation } \\
\text { moment by 23:59 on the same day }\end{array}$ & 11,00 & 5,50 \\
\hline $24 \mathrm{~h}+$ & $\begin{array}{l}\text { The personal ticket valid in the ZTM area and on all } \\
\text { Koleje Śląskie railway lines in the GZM area for 24 } \\
\text { hours from the date and time selected during the } \\
\text { purchase or from the date and the time of purchase or } \\
\text { from the moment of activation }\end{array}$ & 15,00 & 7,50 \\
\hline
\end{tabular}

The table 4 and 5 present the pricelist of long-term tickets issued in electronic form. The table 4 presents the pricelist of non-personalized tickets and the table 5 presents the pricelist of personalized tickets.

Table 4. The pricelist of long-term non-personalized tickets issued in electronic form [9]

\begin{tabular}{|c|l|c|c|}
\hline $\begin{array}{c}\text { The symbol } \\
\text { of the ticket }\end{array}$ & The type of ticket & $\begin{array}{c}\text { Normal } \\
\text { ticket price } \\
{[\mathrm{PLN}]}\end{array}$ & $\begin{array}{c}\text { Half-price } \\
\text { ticket price } \\
{[\mathrm{PLN}]}\end{array}$ \\
\hline 7-days & $\begin{array}{l}\text { Valid for the entire ZTM network for 7 days from } \\
\text { the date selected during the purchase }\end{array}$ & 50,00 & 25,00 \\
\hline $\begin{array}{c}\text { The } \\
\text { network } \\
30\end{array}$ & $\begin{array}{l}\text { Valid for the entire ZTM network for 30 days from } \\
\text { the date selected during the purchase }\end{array}$ & 190,00 & 95,00 \\
\hline
\end{tabular}


Table 5. The pricelist of long-term personalized tickets issued in electronic form [9]

\begin{tabular}{|c|l|c|c|}
\hline $\begin{array}{c}\text { The symbol } \\
\text { of the ticket }\end{array}$ & \multicolumn{1}{|c|}{ The type of ticket } & $\begin{array}{c}\text { Normal } \\
\text { ticket price } \\
{[\text { PLN] }}\end{array}$ & $\begin{array}{c}\text { Half-price } \\
\text { ticket price } \\
{[\text { PLN] }}\end{array}$ \\
\hline City 30 & $\begin{array}{l}\text { Valid for 1 City for 30 days from the date selected } \\
\text { during the purchase }\end{array}$ & 99,00 & 49,50 \\
\hline 2 Cities 30 & $\begin{array}{l}\text { Valid for 2 Cities for 30 days from the date } \\
\text { selected during the purchase }\end{array}$ & 139,00 & 69,50 \\
\hline $\begin{array}{c}\text { The network } \\
30\end{array}$ & $\begin{array}{l}\text { Valid for the entire ZTM network for 30 days from } \\
\text { the date selected during the purchase }\end{array}$ & 159,00 & 79,50 \\
\hline City 90 & $\begin{array}{l}\text { Valid for 1 City for 90 days from the date selected } \\
\text { during the purchase }\end{array}$ & 260,00 & 130,00 \\
\hline 2 Cities 90 & $\begin{array}{l}\text { Valid for 2 Cities for 90 days from the date } \\
\text { selected during the purchase }\end{array}$ & 359,00 & 179,50 \\
\hline The network & $\begin{array}{l}\text { Valid for the entire ZTM network for 90 days from } \\
\text { the date selected during the purchase }\end{array}$ & 399,00 & 199,50 \\
\hline The network & $\begin{array}{l}\text { Valid for the entire ZTM network for 120 days } \\
\text { from the date selected during the purchase }\end{array}$ & 480,00 & 240,00 \\
\hline The network & $\begin{array}{l}\text { Valid for the entire ZTM network for 180 days } \\
\text { from the date selected during the purchase }\end{array}$ & 550,00 & 275,00 \\
\hline W-20 & $\begin{array}{l}\text { Valid for 20 trips on the entire ZTM network for } \\
180 \text { days from the date selected during the } \\
\text { purchase }\end{array}$ & 60,00 & 30,00 \\
\hline W-40 & $\begin{array}{l}\text { Valid for 40 trips on the entire ZTM network for } \\
180 \text { days from the date selected during the } \\
\text { purchase }\end{array}$ & 110,00 & 55,00 \\
\hline W-80 & $\begin{array}{l}\text { Valid for 80 trips on the entire ZTM network for } \\
180 \text { days from the date selected during the } \\
\text { purchase }\end{array}$ & 200,00 & 100,00 \\
\hline
\end{tabular}

The table 6 presents the pricelist of the monthly METROTICKETS issued in electronic form.

Table 6. The pricelist of long-term personalized tickets issued in electronic form [10]

\begin{tabular}{|c|l|c|c|}
\hline $\begin{array}{c}\text { The symbol } \\
\text { of the ticket }\end{array}$ & \multicolumn{1}{|c|}{ The type of ticket } & $\begin{array}{c}\text { Normal } \\
\text { ticket price } \\
{[\text { PLN] }}\end{array}$ & $\begin{array}{c}\text { Half-price } \\
\text { ticket price } \\
{[\text { PLN] }}\end{array}$ \\
\hline $\begin{array}{c}\text { Katowice } \\
\text { zone }\end{array}$ & $\begin{array}{l}\text { Valid in public transport organized by ZTM and at } \\
\text { all KŚ railway lines within the city Katowice }\end{array}$ & 119,00 & 59,50 \\
\hline Red & $\begin{array}{l}\text { Valid in public transport organized by ZTM and at } \\
\text { KŚ railway line: Dąbrowa Górnicza Sikorka } \\
\text { Katowice zone (inclusive) }\end{array}$ & 179,00 & 89,50 \\
\hline Blue & $\begin{array}{l}\text { Valid in public transport organized by ZTM and at } \\
\text { KŚ railway line: Bierun - Katowice zone } \\
\text { (inclusive) }\end{array}$ & 179,00 & 89,50 \\
\hline Orange & $\begin{array}{l}\text { Valid in public transport organized by ZTM and at } \\
\text { KŚ railway lines: Tychy Lodowisko - Katowice } \\
\text { zone (inclusive), Łaziska Górne Brada - Katowice } \\
\text { zone (inclusive), Kobiór - Katowice zone } \\
\text { (inclusive), Łaziska Średnie - Katowice zone } \\
\text { (inclusive) }\end{array}$ & 179,00 & 89,50 \\
\hline
\end{tabular}




\begin{tabular}{|c|l|c|c|}
\hline $\begin{array}{c}\text { The symbol } \\
\text { of the ticket }\end{array}$ & \multicolumn{1}{|c|}{ The type of ticket } & $\begin{array}{c}\text { Normal } \\
\text { ticket price } \\
\text { [PLN] }\end{array}$ & $\begin{array}{c}\text { Half-price } \\
\text { ticket price } \\
\text { [PLN] }\end{array}$ \\
\hline Green & $\begin{array}{l}\text { Valid in public transport organized by ZTM and at } \\
\text { KŚ railway lines: Gliwice - Katowice zone } \\
\text { (inclusive), Knurów - Gliwice }\end{array}$ & 179,00 & 89,50 \\
\hline Yellow & $\begin{array}{l}\text { Valid in public transport organized by ZTM and at } \\
\text { KŚ railway line: Tarnowskie Góry - Katowice } \\
\text { zone (inclusive) }\end{array}$ & 179,00 & 89,50 \\
\hline $\begin{array}{c}\text { The } \\
\text { Metropolis }\end{array}$ & $\begin{array}{l}\text { Valid in public transport organized by ZTM and at } \\
\text { all KŚ railway lines }\end{array}$ & 229,00 & 114,50 \\
\hline
\end{tabular}

The table 7 presents the pricelist of "Group ticket for 5 people" issued in paper and electronic form.

Table 7. The pricelist of "Group ticket for 5 people" issued in paper and electronic for [9]

\begin{tabular}{|l|l|c|c|}
\hline $\begin{array}{c}\text { The symbol } \\
\text { of the ticket }\end{array}$ & The type of ticket & $\begin{array}{c}\text { Normal } \\
\text { ticket price } \\
\text { [PLN] }\end{array}$ & $\begin{array}{c}\text { Half-price } \\
\text { ticket price } \\
\text { [PLN] }\end{array}$ \\
\hline $\begin{array}{l}\text { Group ticket } \\
\text { for 5 people }\end{array}$ & $\begin{array}{l}\text { Valid for a single ride within three or more cities } \\
\text { or for 90 minutes from validation (with the } \\
\text { possibility of transfer connections) }\end{array}$ & 119,00 & 59,50 \\
\hline
\end{tabular}

\section{Ticket distribution channels}

In the Górnośląska- Zagłębiowska Metropolis there are two types of tickets: paper and electronic. Both types of tickets can be bought in different ways.

Passengers can purchase tickets for a trip in the following way:

- $\quad$ in one of sale points,

- $\quad$ in one of passenger service points,

- in one of solar ticket vending machines,

- $\quad$ through one of available applications,

- $\quad$ in one of ŚKUP ticket vending machines,

- $\quad$ in buses, trams and trolleybuses,

- $\quad$ through client portal in the Internet [13].

First of all, ticket can be bought in points of sale. In the Górnośląska- Zagłębiowska Metropolis there are 523 points of sale, which location is presented in figure 1 [14].

As we can see, the most sale points are located in Katowice (114 points of sale) and the least sale points are located in Bobrowniki, Jaworzno, Łaziska Górne, Mierzęcice, Ornotowice, Sławków, Sośnicowice, Świerklaniec, Toszek, Wojkowice, Zbrosławice, Żory (1). 


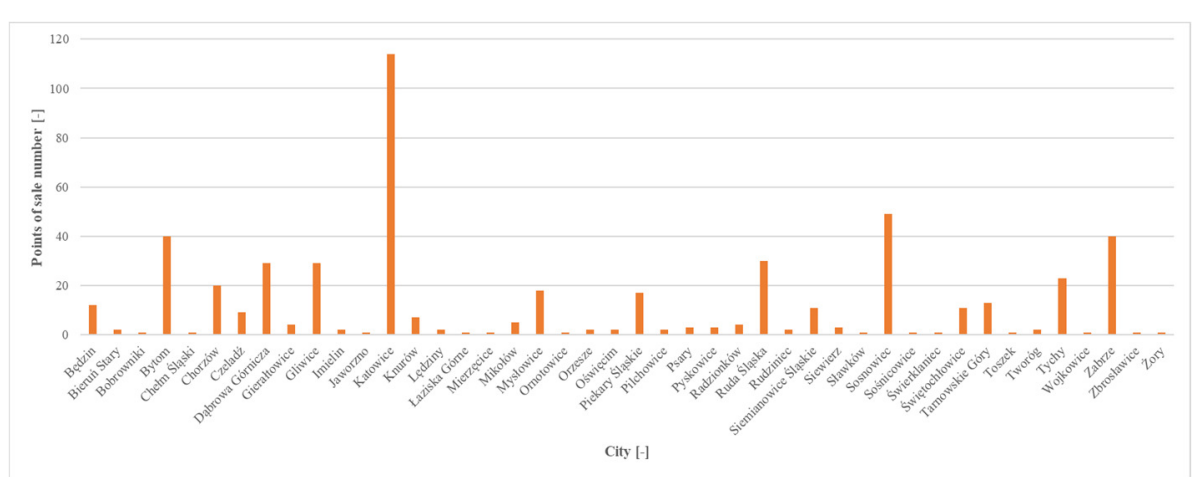

Figure 1. The sale points number in Metropolis cities

The average number of points of sale in Metropolitan cities is almost 12. This number is sufficient to ensure proper communication service for passengers. In sale points we can purchase single tickets, group ticket and encode the electronic ticket on the ŚKUP card, so we can buy each type of ticket. Passenger can pay in cash or by credit card. Another ticket distribution channel is passenger service point. In the GZM area there are 10 passenger service points, which location is presented in the figure 2 [15].

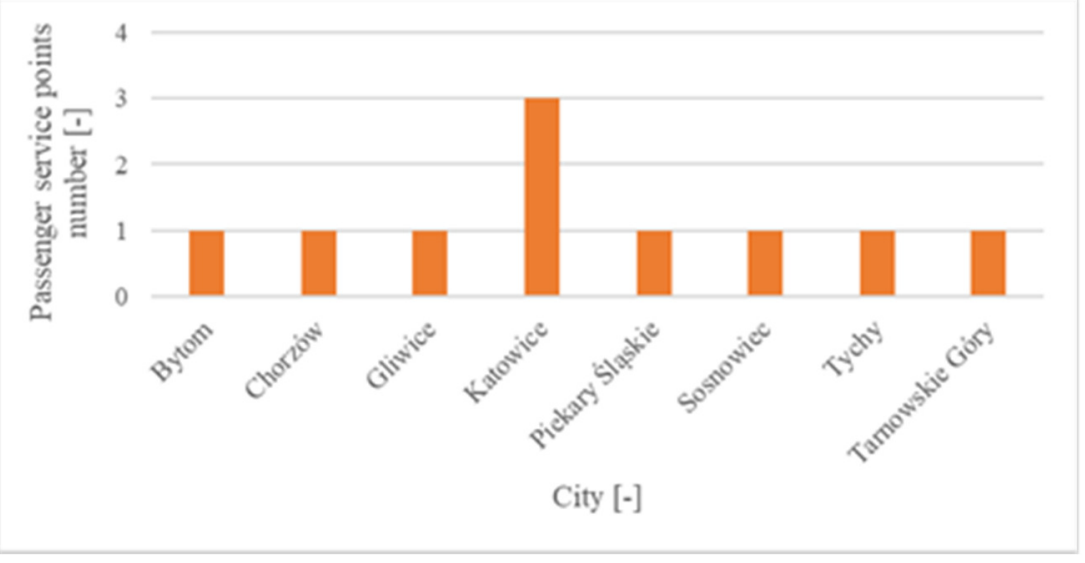

Figure 2. Passenger service points number in Metropolis cities

As we can see, the most passenger service points number are located in Katowice ( 3 points). This is a small number, but it is observed, that passengers prefer Internet service.

In passenger service point we can purchase single tickets, group ticket and encode the electronic ticket on the ŚKUP card, so we can buy each type of ticket. Passenger can pay there in cash, by credit card on by ŚKUP card.

Another ticket distribution channel is solar ticket vending machine. In the GZM area there are 10 solar ticket vending machines, which location is presented in the figure 3 [16]. This number seems far too small, but it is planned to increase number of solar ticket vending machines in the Metropolis. 


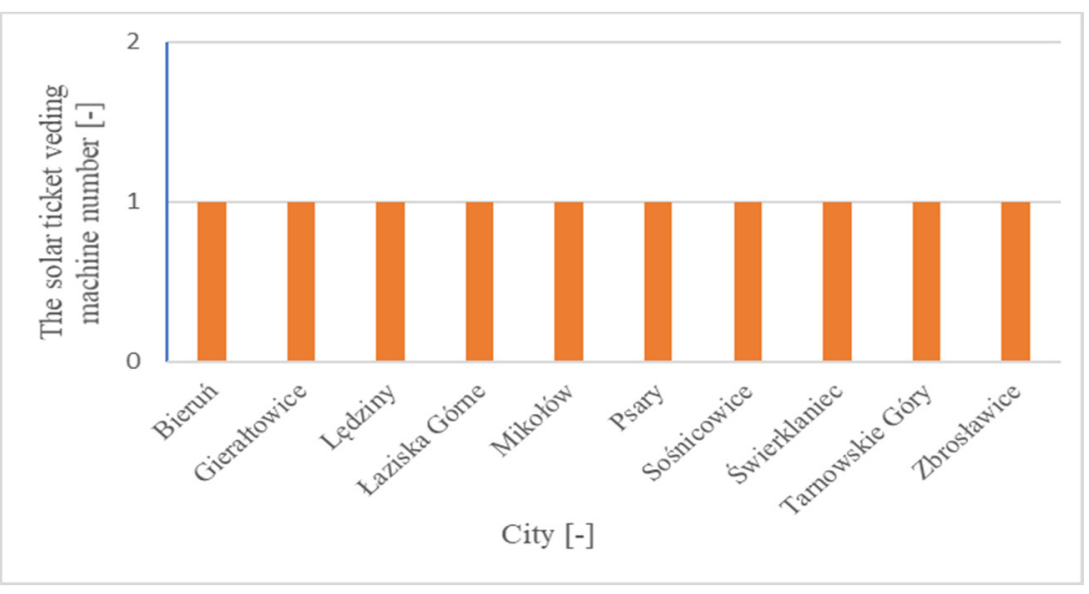

Figure 3. Solar ticket vending machines number in Metropolis cities

In solar ticket vending machines we can purchase single tickets, group ticket and midterm ticket (day pass). Possible payment methods are cash and credit card.

Passenger can buy ticket in mobile application as well: Skycash, mPay, jakdojade, moBILET, and mobilny ŚKUP. By applications passenger can buy tickets in electronic form.

The Skycash, mPay, moBILET, jakdojade apps let passenger buy single tickets, midterm tickets and group ticket. There are more various services available in this applications, for instance: parking service, railway tickets or highway charges. Passenger can pay only by credit card.

The Mobilny ŚKUP application offer passengers to buy every type of ticket. The only condition is having the ŚKUP card, assigned to application. In this application passenger can pay by credit card or ŚKUP card.

Another ticket distribution channel is ŚKUP ticket vending machine. There are 121 ŚKUP ticket vending machines throughout the Metropolis [16].

In the figure 6, the location of ŚKUP ticket vending machines is presented.

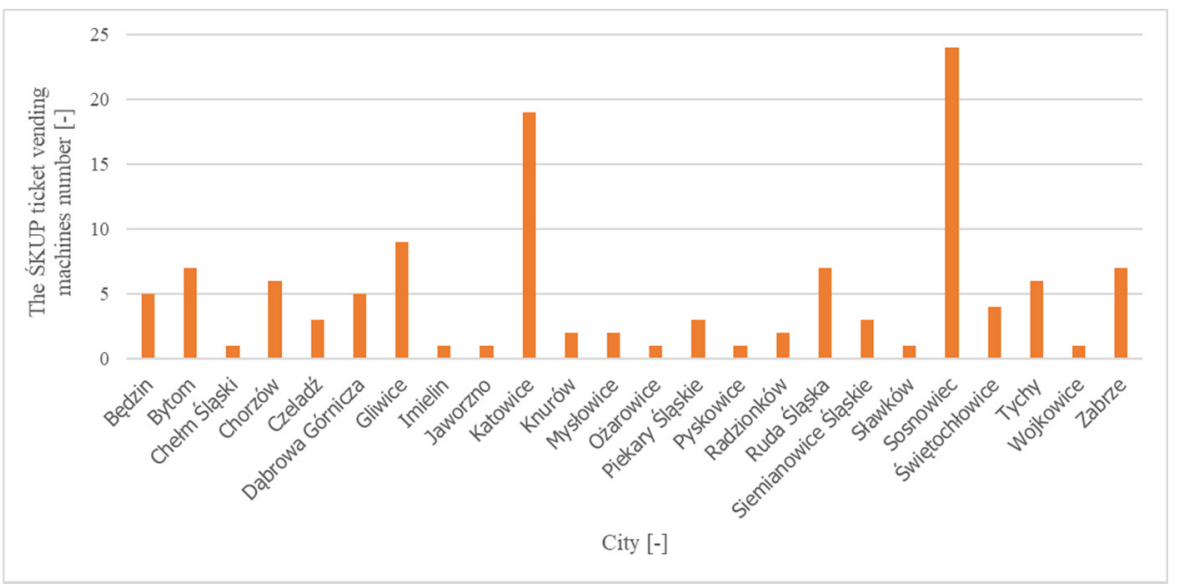

Figure 4. The ŚKUP ticket vending machines number in Metropolis cities 
As we can see, the most ŚKUP ticket vending machines are located in Sosnowiec (24 machines) and the least in Chełm Śląski, Imielin, Jaworzno, Ożarowice, Pyskowice, Sławków and Wojkowice (1 machine). The average number of ŚKUP ticket vending machines in Metropolitan cities is 3 . This number is not enough to ensure proper passenger service. In ŚKUP ticket vending machines we can purchase tickets in paper and electronic form. Tickets bought in electronic form are encoded on the ŚKUP card. Possible payment methods are cash, credit card and ŚKUP card. Passenger can also buy ticket through client portal in the Internet. Through this ticket distribution channel we can purchase tickets only in electronic form. By client portal we can just buy tickets, which will be encoded on the ŚKUP card. Last way to buy ticket in Metropolis area is purchasing ticket in bus, tram or trolleybus. Sigle tickets are sold there by bus drivers. The only possible payment is cash. In addition, in some buses in Tychy there are located tickets vending machines. Passenger can purchase there single tickets paying by credit card.

\section{Summary}

Nowadays it is important to ensure people access to public transport at a good level. To achieve it, the transport offer should be adapted to different groups of people. Based on the information presented in this article, the following conclusions can be formulated:

- $\quad$ the ticket tariff gives passenger information about types of tickets available to purchase,

- $\quad$ in the Metropolis area there are tickets in paper and electronic form,

- $\quad$ tickets purchased in electronic form are cheaper than in paper form,

- there are tickets with different duration,

- passenger, who wants buy ticket, can do it in many ticket distribution channels,

- $\quad$ there are various methods of payment in every ticket distribution channel.

\section{LITERATURE}

1. MACIOSZEK E., LACH D.: Comparative analysis of the results of general traffic measurements for the Silesian Voivodeship and Poland. Scientific Journal of Silesian University of Technology. Series Transport. Volume 100, 2018, p. 105-113.

2. KUREK, A, ŚWIERK, P, MACIOSZEK, E.: Rozwiązania zmniejszające zatłoczenie w miastach jako czynnik mogący poprawić stan bezpieczeństwa ruchu drogowego na terenach zabudowanych. Transport Miejski i Regionalny 09-10 2020, s. 20-29.

3. KUREK A., MACIOSZEK E., ŚWIERK P.: Narzędzie ITS wspomagające zarządzanie informacją o ruchu w mieście - studium przypadku na przykładzie miasta dużej wielkości zlokalizowanego w Polsce, [w:] Galińska B. (red.): Współczesne aspekty zarządzania logistyką. Monografie Politechniki Łódzkiej, Łódź 2019, s. 79-96.

4. LACH D., MACIOSZEK E.: Analiza wybranych usług ITS wykorzystywanych w publicznym transporcie zbiorowym. Prace Naukowe Politechniki 
Warszawskiej. Seria: Transport z. 121. Problemy Transportu w Inżynierii Logistyki - część 4. str. 211-222. Oficyna Wydawnicza Politechniki Warszawskiej. Warszawa 2018.

5. DĘBOWSKA MRÓZ M., FERENSZTAJN-GALARDOS E., KRAJEWSKA R., ROGOWSKI A.: Systemy taryfowe w komunikacji miejskiej w wybranych miastach. Autobusy : technika, eksploatacja, systemy transportowe. R19, nr 12, 2018 s. 1036-1044.

6. JACKIEWICZ J., CZECH P., BARCIK J.: System taryfowo-biletowy stosowany w komunikacji miejskiej - część 1. Zeszyty naukowe Politechniki Śląskiej, Seria: Transport z. 67, 2010 s. 67-74.

7. ŁADA M.: Integracja taryfowa w obszarach metropolitalnych jako istotny element kształtowania oferty transportu zbiorowego. Transport Miejski i Regionalny, nr 11,2015 s. 26-31.

8. WYSZOMIRSKI O. (red): Transport miejski. Ekonomika i organizacja. Wydawnictwo Uniwersytetu Gdańskiego. Gdańsk 2008

9. Uchwała nr 223/2021 Zarządu Górnośląsko- Zagłębiowskiej Metropolii z dnia 26 sierpnia 2021 r. w sprawie przyjęcia „Taryfy przewozu osób i bagażu w komunikacji zbiorowej organizowanej przez Zarząd Transportu Metropolitalnego (ZTM)"

10. Strona internetowa Górnośląsko- Zagłębiowskiej Metropolii: https://metropoliagzm.pl/metropolia-dzis/ (25.10.2021)

11. Strona internetowa ZTM: https://www.metropoliaztm.pl/pl/s/od-stycznia-zarzadtransportu-metropolitalnego (25.10.2021)

12. Strona internetowa ZTM: https://rj.metropoliaztm.pl/ (25.10.2021)

13. Strona internetowa ZTM: https://www.metropoliaztm.pl/pl/s/kup-bilet-i-doladujskup-2021 (26.10.2021)

14. Strona internetowa ZTM: https://www.metropoliaztm.pl/pl/s/punkty-sprzedazy (26.10.2021)

15. Strona internetowa ZTM: https://www.metropoliaztm.pl/pl/s/punkty-obslugipasazera $(26.10 .2021)$

16. Strona internetowa ZTM: https://www.metropoliaztm.pl/pl/s/biletomaty (26.10.2021) 